\title{
Gibellina, Salaparuta, Poggioreale and Montevago: about built environment underutilization and possible urban future
}

\author{
Viviana Pappalardo $*, 1$, Francesco Martinico $^{1}$ \\ (1) Università di Catania, Dipartimento Ingegneria Civile e Architettura \\ Article history: received August 1, 2019; accepted January 15, 2020
}

\begin{abstract}
Disasters like earthquakes affect dramatically the construction of place identity. Urban settlements generate complex social structures that are not just scenarios where the functioning of city takes place. "Interrupted landscapes" cannot be merely reconstructed. Post-earthquake reconstruction lies in between community social identity protection and urban planning approaches to renewal or rebuilding. This paper focuses on the four urban centres of Gibellina, Montevago, Salaparuta and Poggioreale that were reconstructed in a different place after the Belice's earthquake (Western Sicily), occurred in 1968. After a brief review of the planning events that characterized the post-earthquake reconstruction, this paper analyses the built environment of these four settlements with regard to built up volumes, land uses and inhabitants. The most relevant outcome is an impressive underutilization of the reconstructed dwellings and evident trends of depopulation and ageing. Literature and data analysis suggest some critical consideration about the urban strategies adopted, the choices that managed the reconstruction, and the long-term effects caused by the 1968 event. The case studies presented here discuss the directions for the revitalisation of these area from a town planning perspective, taking into account the present and future challenges for resident communities and local authorities, encountering the risk of progressive abandonment of these settlements.
\end{abstract}

Keywords: Belice’s earthquake; planning and policy aspects; Heritage for Italian society.

\section{Introduction}

In the night between $13^{\text {th }}$ and $14^{\text {th }}$ January 1968 a 6.4 magnitude earthquake hits an area of about $6,200 \mathrm{~km}^{2}$ in Western Sicily corresponding approximately with the watershed of the Belice river. The official number of casualties was 231. Twelve municipalities, in the provinces of Agrigento, Palermo and Trapani, suffered the major effects. Gibellina, Poggioreale, Salaparuta and Montevago were almost completely destroyed and were the only towns reconstructed in a different place (INGV, 2019).

All reconstruction processes may function as case studies for investigating the complex interrelation among post-event planning, cultural and economic development; all these factors are not only affected by the current demographic trends but can also greatly influence these trends.

Urban planning approaches to risk, initially focused on the paradigms of pre-disaster prevention and post- 


\section{Viviana Pappalardo et al.}

disaster reconstruction, start to embrace the dimension of the community and urban resilience [Lu and Xu, 2018] only recently, thus being totally ignored when the earthquake event destroyed the towns of the Belice Valley.

Despite the increasing attention payed to the resilience theory and its implications on urban planning and processes, there is relatively little knowledge available to planners, policy makers and designers on how to physically design for resilience. This applies to new developments as well as the reconstruction of destroyed cities. The reason of the complexity that hampers the transition from a theoretical dimension of resilience to urban practice might be related to the variety of definitions of the resilience concept [Meerow et al., 2016] and thus to a misunderstanding about its significance for the discipline and relevance for the urban planning practice.

Investigating the urban resilience implies the analysis of a city in terms of "dimensions" and functioning relations. In order to enhance the resilience of an urban system some actions need to be taken for achieving key goals in four categories: health and well-being, economy and society, infrastructure and environment, leadership and strategy [Arup, 2014].

In the "Infrastructure \& Environment" dimension, the main discussion concerns the provision and the enhancement of natural and man-made critical services. More generally, reference is made to the "built environment" as the product shaped by the overlap between the built and the unbuilt part of the environment, culture and nature, physical and social capital [Hassler et Kohler, 2014].

In particular, the influence of urban morphology on the resilience of cities following an earthquake has been investigated, for example, by Allan et al. [2013], with the aim to provide empirical evidences of the relationship between the community's adaptive behaviour and the spaces of the city, investigating the role of the urban designer in earthquake-prone cities.

Previously, Campanella [2008] argued that plans to rebuild the physical infrastructure of the city must be accompanied by a commitment to rehabilitate its social fabric and communal networks. Interestingly, the author also added that only with strong citizen involvement, the rebuilding of the city will provide a more robust and inclusive urban entity, rather than a "theme-park shadow of its former self", which is instead what happened to the four centres in the Belice area, especially in Gibellina.

The concept of resilience has not been widely applied to rural context or inner areas from a comprehensive perspective and considering all the economic, social and environmental dimensions, though the same concept could be suitably applied to analyse the response of inner centres to specific issues pertaining rural areas [Sanchez-Zamora et al., 2014].

Indeed, the four above mentioned centres belonging to the Belice area, are part of those towns, rural areas and small municipalities that are the prevalent parts of the Italian polycentric system, and are opposed to those larger towns and cities that attract people mostly. This is also due to an easier access to the essential services such as education, mobility and healthcare [Barca and Lucatelli, 2014].

In Sicily, more remote and historically deprived rural areas have suffered from a lengthy and steady period of abandonment in favour of urban areas, and this happened mainly in relation to the disappearing of mining industry and, more recently, to the restructuring of traditional manufacturing and agriculture. After the earthquake occurred in January 1968, Gibellina, Salaparuta, Poggioreale and Montevago have been affected from a shrinking trend, more or less heavily, which started in the fifties and then accelerated after the event.

Broadly speaking, the combination of several processes is at the origin of the shrinking phenomenon. Indeed, these include the decreasing of fertility rate as well as the disappearance of some kind of jobs due to globalization effects or technological changes. Although the phenomenon of shrinking cities could appear a marginal problem at the global level of the urbanizing world [World Economic Forum, 2018], depopulation in almost all of the small towns located in Italian inner areas, is giving rise to a great concern [Murgante and Rotondo, 2012].

Sicily has about 5 million inhabitants - with a high rate of elderly population $(19.3 \%)$ - of which only $3.4 \%$ lives in rural areas, while $50.1 \%$ lives in those areas classified as neither fully rural nor urban. It is an Italian insular region among the less developed, where about 97\% of the total area is classified as rural [EC, 2019].

Gibellina, Salaparuta, Poggioreale are considered “intermediate rural areas”, while Montevago belongs to the group of rural areas with problems in development process (Source: PSR Sicilia 2014/2020).

Actually, these municipalities are not included in the 72 pilot areas of the National Strategy for Inner Areas [ENRD, 2018], but share similar challenges such as marginalisation and population decline, job cuts, degradation of building stock and heritage, reduction of public and private services.

In general, this is also the reason why the backwardness of inner rural areas is faced through the provision of 
conspicuous funds to support rural development at European level.

In spite of recognized criticalities, these areas of the country are ascribed with a high development potential and still contain important environmental and cultural resources. They are also extremely diversified, as the result of their varied natural systems, and centuries' old settlement processes.

Complex unsolved challenges mainly related to the decline of inner areas and the post-earthquake reconstruction concurrently interfere in the territorial dynamics of Gibellina, Salaparuta, Poggioreale and Montevago and in those of other urban settlements within the Belice Valley.

Accordingly, the progressive decline of the valley has triggered an unfinished discussion about the search for a way forward [Badami, 2012; Sessa, 2012; Campo, 2005; Cagnardi, 1981, Renna et al., 1979; Pacelli and De Felice, 1977].

In this paper we focus on the analysis of some changes that have affected the four considered centres in terms of population and housing, as well as on other issues related to the dynamics that followed the reconstruction. We investigate the ongoing state of urban abandonment and building utilization, that can be considered as an indicator for evaluating the post-disaster reconstruction strategies in rural areas. Finally, we discuss some criticisms for future urban dynamics and look at existing recent phenomena that could potentially support planning strategies and urban policies for steering a sustainable resilient future for this area.

\section{Changes in the cities: population and housing utilization before and after the earthquake}

Demographic trends are compared for the selected urban settlements in Figure 1, which plots the total decennial census population between 1861 and 2011, plus the data from the municipal register office at the $31^{\text {st }}$ December 2018. Yet before the earthquake, all the four centres started to lose population [Pinzello et al., 2012], after a period characterized by a slight increase from the turn of the nineteenth to the twentieth century. With the only exception of Montevago, the period from the sixties to the seventies is characterised by a severe reduction of population, varying between $24 \%$ and $30 \%$. A change in this trend appears in the decade toward the nineties for the two larger towns, but all the four settlements experienced a decline.

Table 1 reports in detail demographic changes in the time-frame from 1961 to 2018, thus including the year when the earthquake occurred. If the tragic event probably is not the only reason at the origin of the decline of the areas, the post-event phase and the reconstruction dynamics certainly have failed the objective of the revitalization hoped for these urban settlements.

Data on buildings' occupancy, collected for 2011 National Census (source: ISTAT Istituto Nazionale di Statistica), apparently confirm only partially the trend toward the abandonment of the rebuilt buildings (Figure 2).

The reason is that they represent only buildings that are not used, but these data cannot depict the progressive tendency that has been affecting those buildings that are only partially occupied. In addition, data reported in Figure 2 confirm the perception that these settlements are not irreversibly decaying, a condition that normally corresponds to high percentages of unutilized buildings.

The ISTAT Census data provide also information about occupied dwellings. Except from the case of Salaparuta, the increase of vacant dwellings, from 1991 till 2011, has grown more than the increase of available ones (see Figure 3 - the position on the y-axis stands for the total number of dwellings; the dimension of the circle represents the number of vacant units). Poggioreale is the emblematic example: the National Census database counts a total amount of 793 dwellings in 1991, 1043 dwellings in 2001 and 1965 units in 2011. Only 635, 686 and 665 of these dwellings are counted as occupied, respectively. Thus, the increase in abandonment, from 1991 to 2011 is $723 \%$, vis-à-vis $148 \%$ increase in the total number of dwellings.

Gibellina and Montevago exhibit a growth of total dwellings as well as occupied and vacant units, whereas Poggioreale and Salaparuta show middle fluctuations. In particular, Salaparuta is the only centre that is characterized by a decrease of both the total dwellings and the vacant and occupied units in the considered time period.

The population density, referred to the total area comprised within the administrative borders of the municipalities of the four centres, is reported in Table 2. 
Viviana Pappalardo et al.

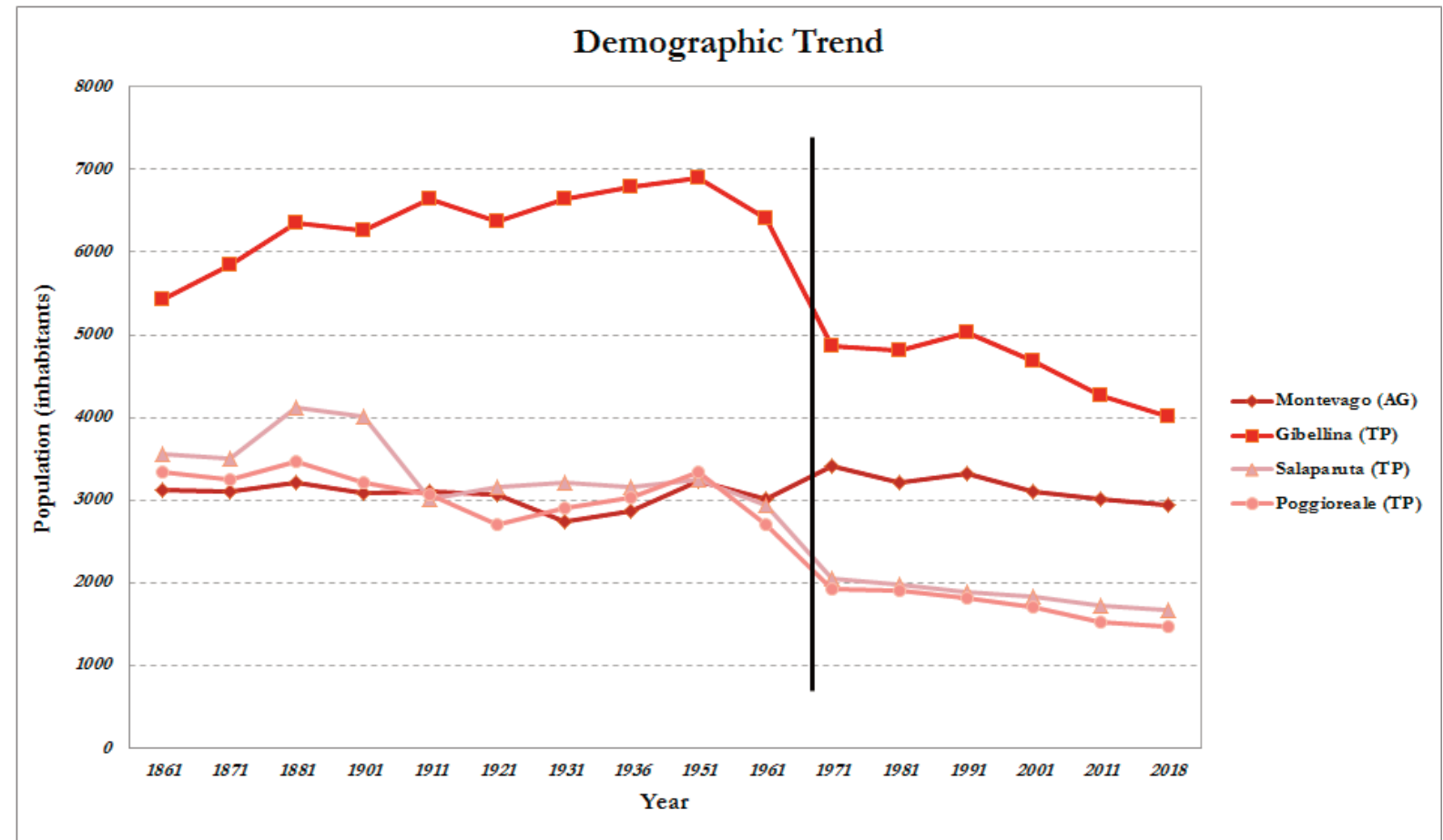

Figure 1. Demographic trend (Source: tuttitalia.it database; demo.istat.it).

\begin{tabular}{|c|c|c|c|c|c|c|c|c|}
\hline Year & Gibellina & $\%$ change & Salaparuta & $\%$ change & $\begin{array}{c}\text { Poggio- } \\
\text { reale }\end{array}$ & $\%$ change & Montevago & \% Change \\
\hline 1961 & 6410 & & 2943 & & 2698 & & 3008 & \\
\hline 1971 & 4865 & & 2048 & & 1926 & & 3418 & \\
\hline $1961-71$ & & -24 & & -30 & & -29 & & +14 \\
\hline 1981 & 4802 & & 1986 & & 1908 & & 3208 & \\
\hline $1971-81$ & & -1 & & -3 & & -1 & & -6 \\
\hline 1991 & 5027 & & 1889 & & 1822 & & 3325 & \\
\hline 1981-91 & & +5 & & -5 & & -5 & & +4 \\
\hline 2001 & 4677 & & 1835 & & 1715 & & 3108 & \\
\hline 1991-01 & & -7 & & -3 & & -6 & & -7 \\
\hline 2011 & 4264 & & 1721 & & 1534 & & 3015 & \\
\hline 2001-11 & & -9 & & -6 & & -11 & & -3 \\
\hline 2018 & 3981 & & 1639 & & 1478 & & 2929 & \\
\hline 2011-18 & & -7 & & -5 & & -4 & & -3 \\
\hline
\end{tabular}

Source: Based on tuttitalia.it database, with updates from demo.istat.it

Table 1. Population of cities of Gibellina, Salaparuta, Poggioreale and Montevago, 1961-2018. 


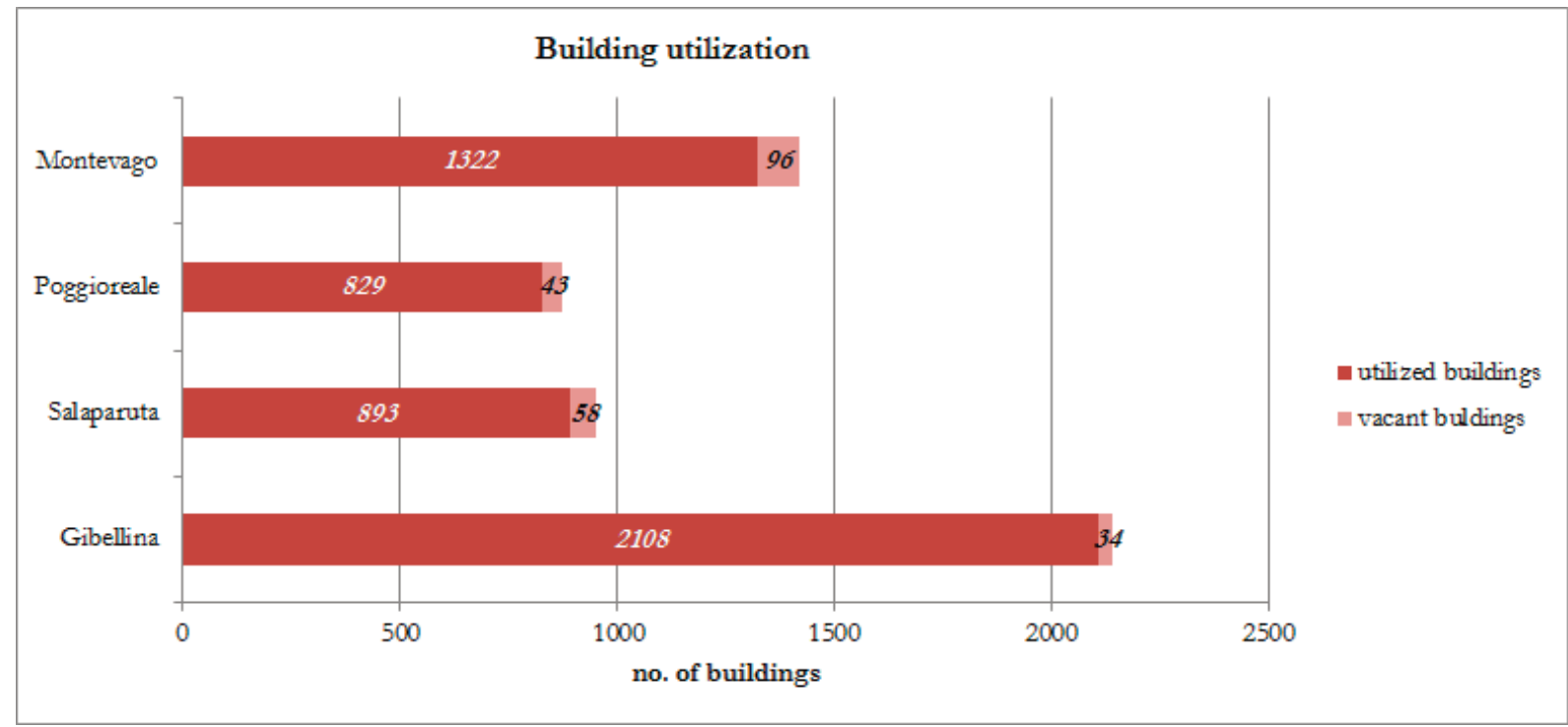

Figure 2. Building utilization (Source: ISTAT National Census 2011).

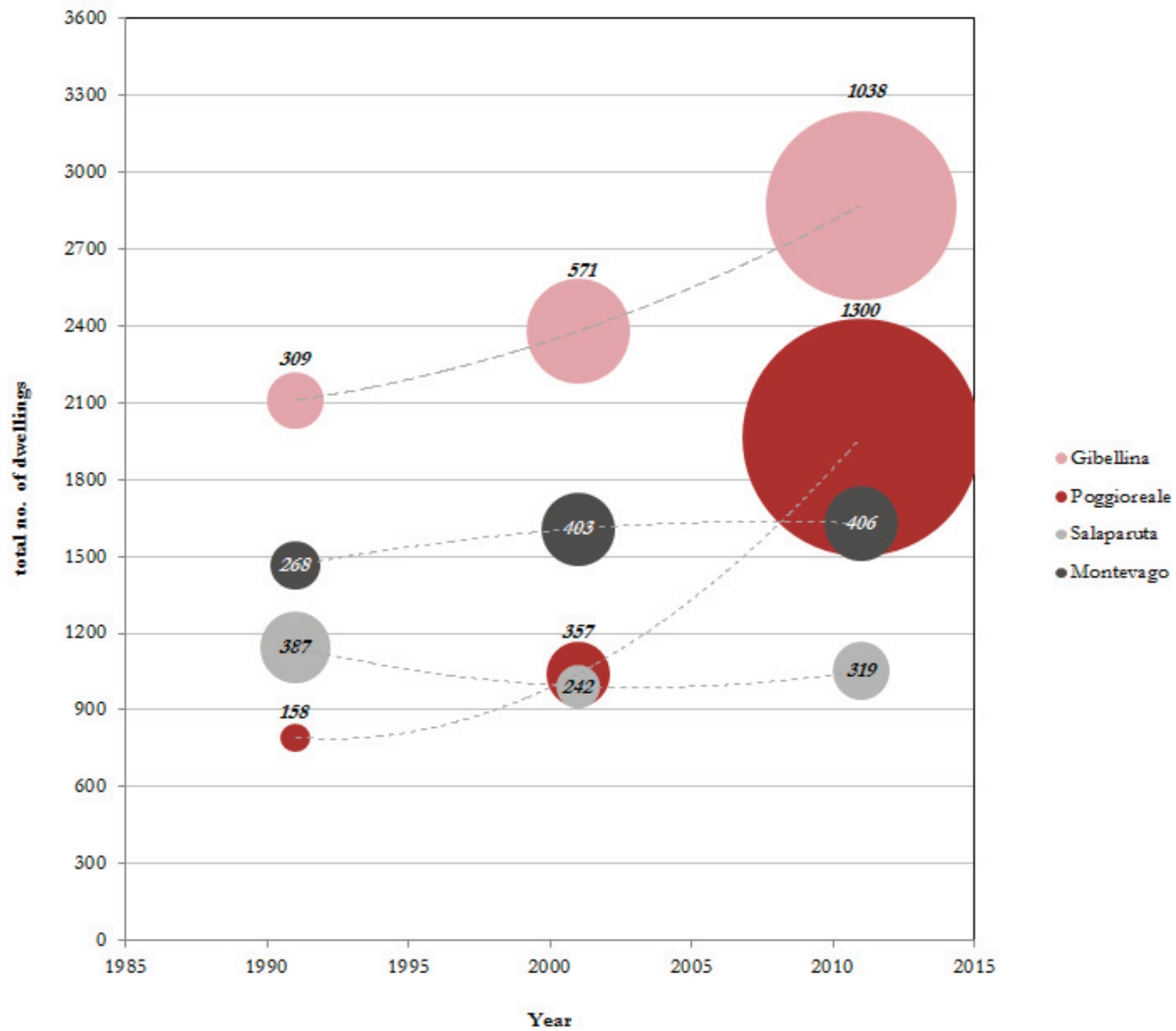

Figure 3. Relation between total and vacant dwellings in the centres of Gibellina, Poggioreale, Salaparuta and Montevago. 
Viviana Pappalardo et al.

\begin{tabular}{|c|c|c|c|c|}
\hline Year 2011 & Gibellina & Salaparuta & Poggioreale & Montevago \\
\hline Area & $46,57 \mathrm{~km} 2$ & $41,42 \mathrm{~km} 2$ & $37,46 \mathrm{~km} 2$ & $32,91 \mathrm{~km} 2$ \\
\hline Density & $91,55 \mathrm{ab} / \mathrm{km} 2$ & $41,55 \mathrm{ab} / \mathrm{km} 2$ & $40,95 \mathrm{ab} / \mathrm{km} 2$ & $91,61 \mathrm{ab} / \mathrm{km} 2$ \\
\hline
\end{tabular}

Table 2. Population density.

Moreover, the analysis of ISTAT data highlights the coincidence between the described shrinking demographic trend and the ageing of inhabitants, so that these areas of the Belice Valley are now characterized by an impressive underutilization of residential buildings but also by significant changes in the age and social profile of local communities (Table 3). In this perspective, also the immigration of foreigners is becoming crucial. The total number of foreign residents is actually low but increasing, with significant percentage if compared to that one of the province of Trapani and of the entire Sicily, especially in Poggioreale and Salaparuta. This presence is mainly due to the role of foreign workers in the agricultural sector. Without this contribution, the demographic decline would appear even more alarming.

\begin{tabular}{|c|c|c|c|c|c|c|}
\hline Year & $\begin{array}{c}\text { Ageing } \\
\text { index } \\
2002\end{array}$ & 2018 & $\begin{array}{c}(2002-2018) \\
\%\end{array}$ & $\begin{array}{c}\text { Foreign } \\
\text { residents } \\
2004\end{array}$ & 2018 & $\begin{array}{c}\% \text { of total } \\
\text { population } \\
\text { (2018) }\end{array}$ \\
\hline Gibellina & 152,1 & 223,6 & $+47,0$ & 68 & 83 & 2,1 \\
\hline Salaparuta & 139,2 & 177,8 & $+27,7$ & 23 & 41 & 2,5 \\
\hline Poggioreale & 159,1 & 246,8 & $+55,1$ & 9 & 95 & 6,4 \\
\hline Montevago & 139,8 & 216,4 & $+54,8$ & 9 & 122 & 4,2 \\
\hline Trapani & 110,4 & 171,6 & $+55,4$ & & & 4,9 \\
\hline Sicily & 99,1 & 149,3 & $+50,7$ & & & 4,0 \\
\hline Italy & 131,4 & 168,9 & $+28,5$ & & & 8,7 \\
\hline
\end{tabular}

Source: Based on tuttitalia.it database

Table 3. Ageing index and foreign residents.

\section{Changes in the cities: urban issues before and after the earthquake}

Before the earthquake, the four centres were inner small rural towns affected by economic depression and marginality, in comparison with the regional and even more with the national level [Campo, 2005]. Production methods and crops typologies were typical of a small scale agricultural economy. In these years, there was the 


\section{Housing underutilization in the Belice}

beginning of the depopulation. The social condition, strongly affected by the aforementioned economic situation, was further worsened by the considerable remoteness of the area and the inadequacy of transport infrastructure [Scibilia, 2016]. Habits and behaviours, traditions and cultures were reflected in the built and unbuilt environment, whose signs have been completely cancelled by the tragic event.

All the four examined centres have been rebuilt after the earthquake in different locations (Figure 4). The relocation characterized by the greater distance from the previous settlement is that one of Gibellina.

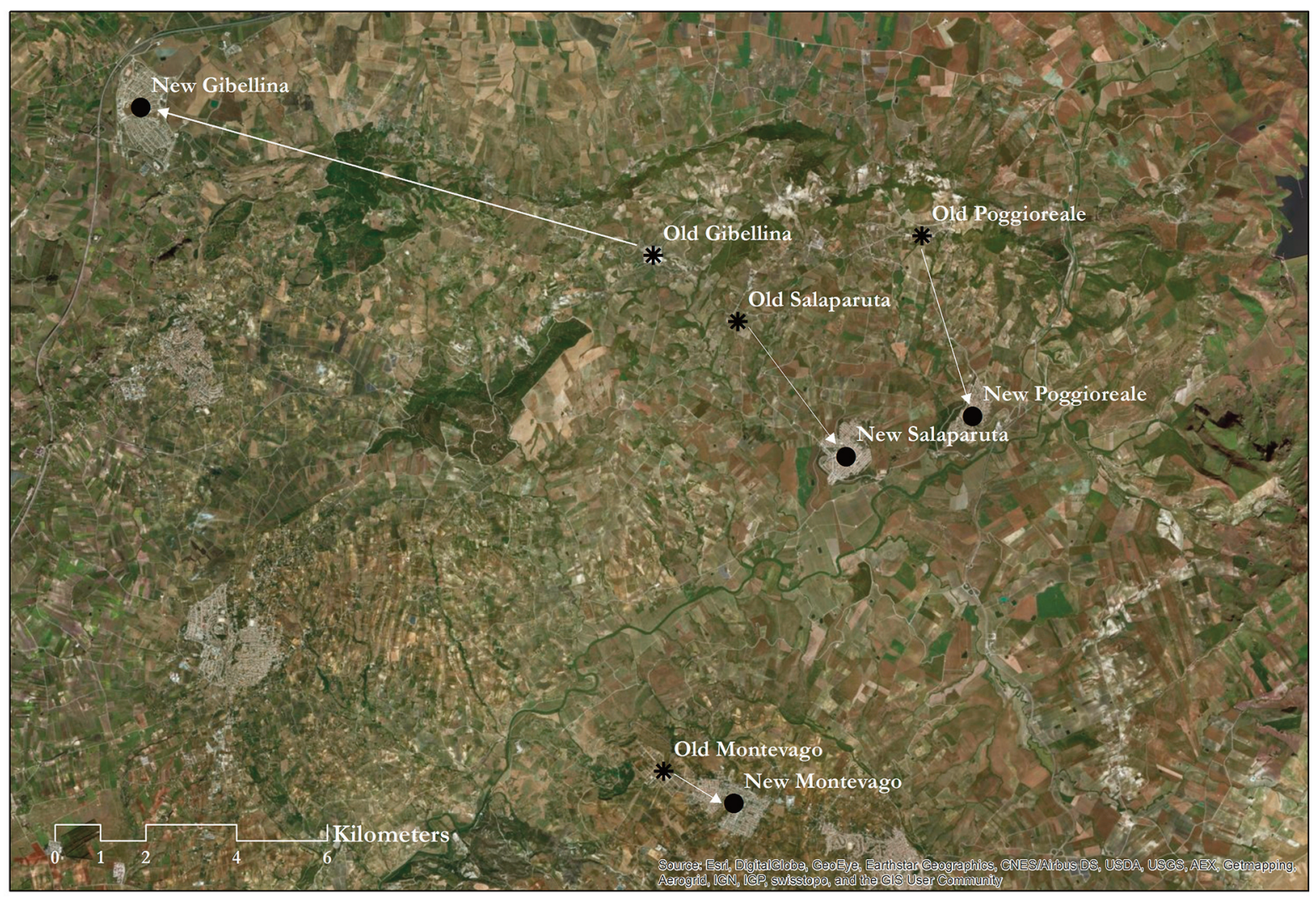

Figure 4. Relocation of the destroyed centres (World Imagery Source: Esri, DigitalGlobe, GeoEye, Earthstar Geographics, CNES/Airbus DS, USDA, USGS, AEX, Getmapping, Aerogrid, IGN, IGP, swisstopo, and the GIS User Community).

At that time, a framework law on detailed rules and methods of interventions in case of disasters was absent. Even though the Government promptly started its interventions, ten years after the disaster the inconsistency of the public action was already undeniable [Pacelli and De Felice, 1977]. Actually, the national Government and the Region both exercised their jurisdiction whilst local authorities remained marginal if not absent in the process [Pinzello et al., 2012]. Starting from the first funds for the reconstruction, which were provided following the approval of the National Law no. 241/1968, a coherent and well-planned program for re-construction operations was missed. What actually happened was a competitive race for subsidies and benefits among the municipalities hit by the earthquake in the Belice Valley [Pacelli and De Felice, 1977]. The objective of the reconstruction was deliberately transformed in a different project and became the chance for implementing extraordinary interventions to support the deprived inner areas. Unfortunately, political forces and representatives from civil society were not able to interpret in the right way the communities, needs [Campo, 2005], so that the earthquake was followed by a battle of the have-nots [Pacelli and De Felice, 1977].

In April 1968, a national agency called Istituto per lo Sviluppo dell'Edilizia Sociale (Institute for Social Housing Development - ISeS) had already been commissioned to plan the reconstruction of the affected areas. Moreover, the Law no. 858/1968 introduced supplementary provisions addressed to give financial support to the areas affected by the earthquake [Scibilia, 2016]. 


\section{Viviana Pappalardo et al.}

In the same year, Piani Territoriali di Coordinamento (Sub-Regional Plans) were conceived aiming at improving the renaissance of the entire Belice Valley, starting from expensive projects for transport infrastructure. Moreover, plans for the delocalization and detailed land use plans were added to the complex framework of approved planning instruments at regional scale. After four years, the most of public utilities such as roads, sewers, and water connections had been completed and regulations and guidelines for planning tools implementation had been provided to municipalities in order to start the reconstruction but, unfortunately, the new houses were had not been yet constructed and the population was occupying temporary shelters [Pinzello et al., 2012].

The whole planning approach was based on the dominant rational-comprehensive development paradigm, however disconnected from local specificities [Piazza, 1994]. The result was a vision coherent with the dominant regional planning paradigm but not related to the real development prospective of the area at that time [Renna et al., 1979]. This vision was focused on connected urban poles containing a planned distribution of integrated public services, a settlement model far away from the traditional town-centred system, which was based on the homeworkplace closeness [Pinzello et al., 2012]. The relation between the planning tools at the sub-regional scale and the local land use plans was not clear [Cagnardi, 1981] while the choice in favour of a rational planning approach was firmly stated. The adopted approach was fully coherent with the planning paradigm of the Sixties, based on a top-down hierarchical design vision which not includes a shared approach, able to involve local communities in determining a common view of their future [Campo, 2005; Cagnardi, 1981].

Accordingly, the community involvement did not play a role in the complex planning system of the reconstruction of the Belice area. Both the Sub-Regional Plans, which were coherent with the dominating ideas at a wider territorial scale [Martinico, 2017], and the Detailed Plans for the delocalization and the reconstruction proposed an idea of settlement infrastructure which was inspired by the modernist models of town planning. Local masterplans were based on an orthodox interpretation of zoning that have produced over-ambitious projects for service buildings and schools. Social housing typologies and features of open space in the new urban settlements were complacent with standard models derived by popular design manuals [Piazza, 1994]. The result was the provision of an anonymous and out-of-context built-up environment (Figure 5) [Sessa, 2012].

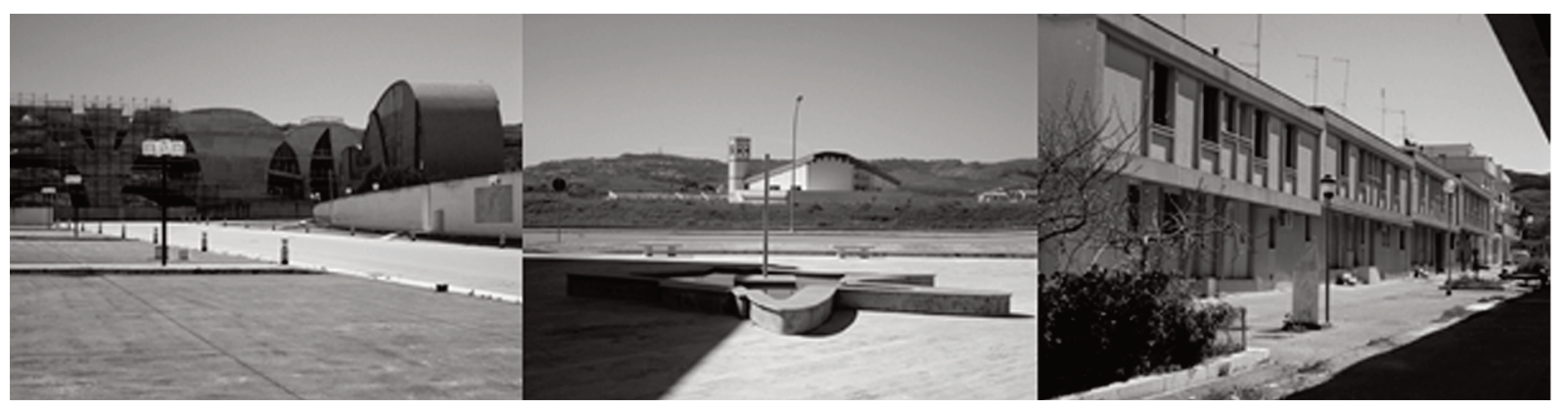

Figure 5. Gibellina (Source: Author, Viviana Pappalardo).

The attempt of introducing contemporary art and high quality architecture, especially in Gibellina, has produced some high quality buildings, some authored by prominent starchitects of that time and celebrated in architectural magazines. The aim was to improve the overall quality of the public realm giving a new sense of identity to the communities.

The case of Gibellina is renown as an exceptional experiment in the usage of culture and the arts [Folkerts, 2015]. However, the attempt to fill the "empty" spaces of the reconstruction and the "interrupted landscapes" [Clemente and Salvati, 2017] by using sculptures, artwork and high quality architectures, was not successful in giving to these places a recognizable urban quality [Piazza, 1994]. Actually, the unquestionable aesthetic and conceptual value of each element turned out to be unrelated to the context, the local culture and the previous urban experience [Scibilia, 2016; Sessa, 2012; Piazza, 1994].

The intention of implementing a polycentric regional city, endowed with a well-structured transport network and industrial estates for hosting modern manufacturing, produced a scattered distribution of 
isolated centres, where community identities were completely disarranged. Models at the base of the industrial development policy in Southern Italy has been already demonstrated to be often unsuccessful, especially when the implemented actions have not been coupled with existing urban poles that had already strong socio-economic structures [Martinico, 2001].

Also in the Belice Valley, the construction of highways and road networks well beyond the actual demand, as well as the design and construction of new towns imagined for new living and working styles, failed the target of triggering a new economic and development that would have included the cultural enrichment of the communities [Campo, 2005; Cagnardi, 1981].

However, the considerable effort in imagining a complete economic renaissance of these inner areas far beyond the mere post-earthquake reconstruction, has produced some positive effects. This consideration is partially supported by the average income data (2016), which show that the economy of the valley is comparable with the rest of inner areas of Sicily even if considerably worse than the national average (Table 4). The National Agriculture Census data on total farming area, show that, despite the overall negative trend started after the 2000, in 2010 the farming area was larger or at least slightly lower than the area in 1982. The exception is Montevago, where the registered decrease is more significant and equal to $26 \%$.

\begin{tabular}{|c|c|c|c|c|c|}
\hline & $\begin{array}{c}\text { taxpayers/ } \\
\text { population \% }\end{array}$ & $\begin{array}{l}\text { average } \\
\text { income }\end{array}$ & $\begin{array}{c}\text { income/ } \\
\text { person }\end{array}$ & $\begin{array}{l}\text { Variation } \\
\text { (Sicily) \% }\end{array}$ & $\begin{array}{c}\text { Variation } \\
\text { (Italy) \% }\end{array}$ \\
\hline Gibellina & 70,80 & 13.409 & 9.491 & $+4,1$ & $-31,7$ \\
\hline Salaparuta & 64,70 & 12.648 & 8.186 & $-10,2$ & $-41,1$ \\
\hline Poggioreale & 65,30 & 12.273 & 8.009 & $-12,2$ & $-42,4$ \\
\hline Montevago & 56,60 & 12.608 & 7.136 & $-21,7$ & $-48,6$ \\
\hline Trapani & 59,60 & 15.042 & 8.969 & $-1,6$ & $-35,5$ \\
\hline Agrigento & 56,10 & 14.279 & 8.016 & $-12,1$ & $-42,3$ \\
\hline Sicily & 56,10 & 16.258 & 9.119 & & $-34,4$ \\
\hline Italy & 66,40 & 20.918 & 13.896 & & \\
\hline
\end{tabular}

Source: Based on MEF- Ministry of Economy and Finance database

Table 4. Income (2016). 


\section{Built environment underutilization}

In order to evaluate the degree of utilization of the reconstructed buildings, we focused on: i) the identification of those buildings with residential destination, ii) the attribution of the cubic volume data to identified buildings, and iii) the matching of population data with cubic volume data for calculating the average cubic volume per person.

Population data provided by ISTAT are not available for all of the census-tracts. For example, the data needed for the Municipality of Gibellina are available only for 19 of the 34 tracts included in municipal borders. The spatial distribution of the inhabitants (Appendix 1) shows the concentration of population in some census-tracts and confirms that urban sprawl is not a relevant phenomenon in this area.

As a first step, we used the available vectorial maps [Carta Tecnica Regionale scale 1: 10.000] to extract the layers containing buildings classified as residential/social/administrative/under construction. Thus, industrial or commercial, schools, hospitals, churches, ruins, cemeteries and others type of constructions were not considered. ArcGis functions have been used to calculate the heights of buildings that were included in the vectorial map: the "Minus" tool of the "spatial analyst toolbox" was been used to subtract the value of the Digital Terrain Model (DTM) input raster from the value of the Digital Surface Model (DSM) input raster, on a cell-bycell basis. The values of the output raster within the features of the buildings map, were summarized by using the "zonal statistic" tool. The average height was finally joined to buildings polygons (Appendix 2).

The location of resident population was modelled using the available 2011 National Census geo-referenced data that are referred to census tracts, the smallest geographical unit to which population data is referred (residents or specific social groups). They are usually proxied by the centroid of each polygonal tract which represents the entire population living there [La Rosa et al., 2016]. For each census-tract area, the maps of the utilization of the building stock were derived by dividing the total cubic volume of residential buildings by the total number of residents.

The map represents the spatial distribution of the index of the residential volume per person. Results indicate the current under-utilization of the four reconstructed urban settlements (Figure 6).

In Italy, the D.M.1444/1968 decree low contains prescriptions on planning standards and recommendations on cubic volumes and square meters per inhabitant (currently approximated to $100-120 \mathrm{~m}^{3}$ /inhabitant and 30$40 \mathrm{~m}^{2}$ /inhabitant).

Particularly in the studied areas, the availability of built volumes per inhabitant indicates values much higher than the standard ones. The maximum value is reached in a census tract in Salaparuta (about $851 \mathrm{~m}^{3} /$ inhabitant), which is almost equal to have more than $250 \mathrm{~m}^{2}$ of living surface per inhabitant available on the average. In these urban centres, the prospective population that can dwell in the current residential building is therefore much higher than 2011 Census population. The situation is even worse if compared with the population registered at the end of 2018. Montevago shows the largest range between the minimum and the maximum value of the index, which varies between $198 \mathrm{~m}^{3} /$ inhabitant and $728 \mathrm{~m}^{3} /$ inhabitant. On the contrary, Poggioreale is characterized by the smallest range with a minimum index of $331 \mathrm{~m}^{3} /$ inhabitant and a maximum of $588 \mathrm{~m}^{3} /$ inhabitant. In Gibellina the cubic volume per person reaches the lowest maximum value (about $572 \mathrm{~m}^{3} /$ inhabitant) but the minimum value is still very high (about $277 \mathrm{~m}^{3} /$ inhabitant). The index is higher than $500 \mathrm{~m}^{3} /$ inhabitant in the $60 \%$ of the census tracts in Poggioreale.

This data is even more worrying if we refer to the continuous downward trend in population in the period 2011-2018 (Poggioreale lost 56 inhabitants, Salaparuta and Montevago more than 80 residents, Gibellina almost 300).

These results confirm that the reconstruction process was designed taking into account an urban capacity of the new towns referred to the demography pre-existing to earthquake, when the Belice was still inhabited by a population engaged in high labour-intensive agricultural activities.

Nevertheless, important limitations exist on the use of the applied methodology. Firstly, in order to obtain a more precise distribution of the population, additional data, such as land-use maps containing information about residential areas, should be used. In fact, the conducted analysis may have led to an overestimation of residential volumes, because it was not possible to take into account all those portions of cubic volume in buildings that hold commercial activities and other kind of services along with residential functions. Secondly, the available geographical dataset (DEM, DSM, Cartographies) and its accuracy strongly influence the results. 
Housing underutilization in the Belice
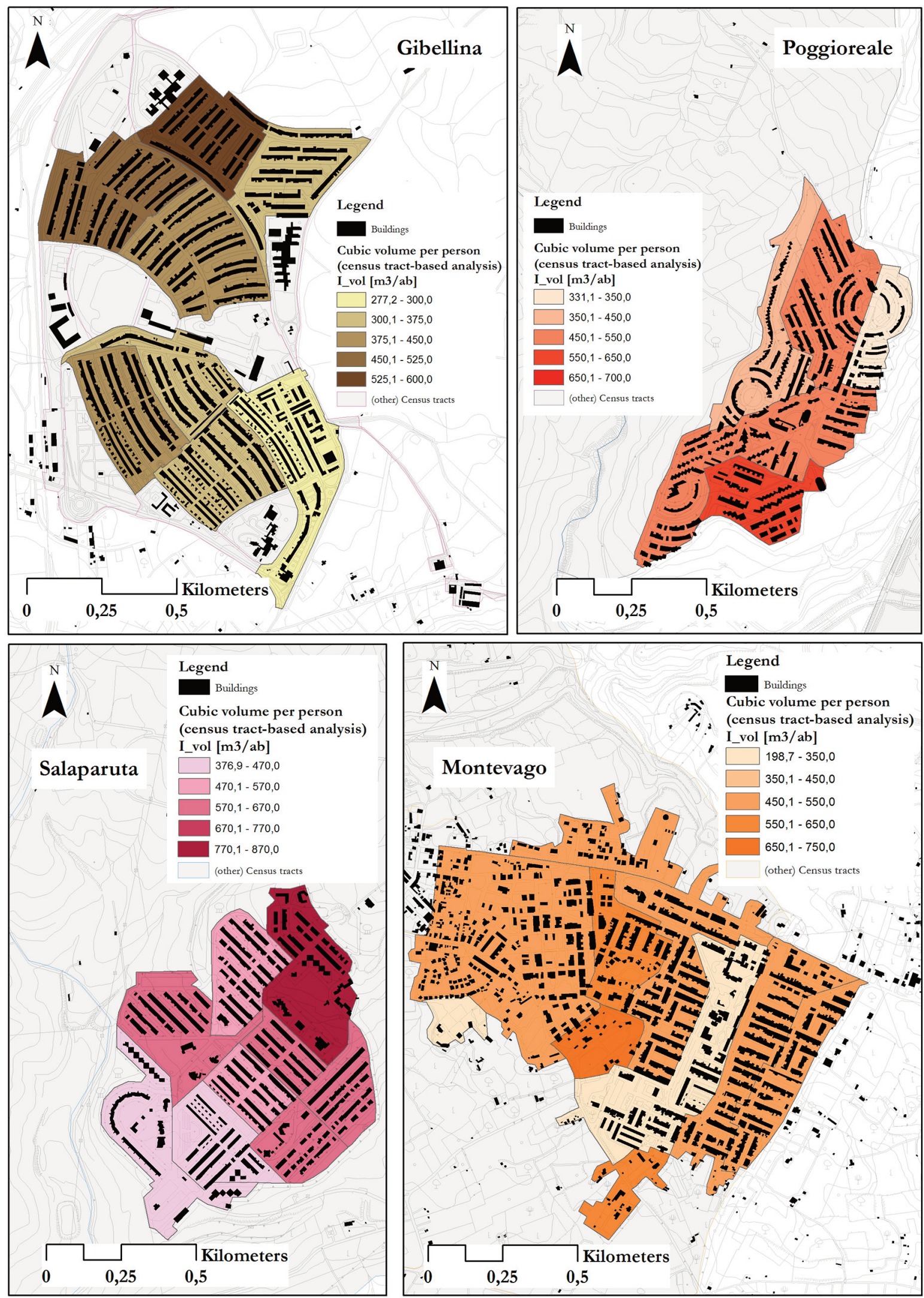

Figure 6. Map of the building stock utilization. 


\section{Viviana Pappalardo et al.}

However, it is clear that the whole reconstruction process requires an in-depth revision today; this is necessary to understand what could be the future of reconstructed centres, considering that the current housing stock is much higher than the current needs of the communities living in this area. The presence of an excessive amount of not used or underused housing, poses new problems for municipalities. For example, the increase of maintenance costs and the risk of a progressive degradation of semi-abandoned neighbourhoods.

\section{Possible urban future}

In 1950, 746 million people lived in urban areas. By 2046, it has been estimated to be over 6 billion. Not surprisingly, the global attention has focused on this rapid century-long urbanisation processes and their social, economic and environmental implications.

In contrast, de-urbanisation receives limited attention and not straightforward solutions are appearing for the serious problems posed by this trend (Word Economic Forum, 2018). What we are encountering now is a different type of problem that is becoming increasingly familiar in both developed and developing countries. A considerable number of countries is experiencing housing surplus due to depopulation or oversupply of dwellings [Lòpez Moreno and Gonzàles Blanco, 2014], a phenomenon that requires a greater attention from policy makers and researchers. This problem is intertwined with that one of ageing population and a growing need of care. The idea of using housing equity to finance consumption in old age is emerging but, in Europe people seldom move to smaller houses after children have left home and this process requires incentives, like reducing real patrimony transfer taxes [Maattanen, 2019].

While new urbanisation is still the main issue in many developing countries, a significant number of cities are witnessing depopulation, discovering that they have built more infrastructure than what is really needed. Among the new problems that are arising a relevant one is finding a way for downsizing the existing infrastructure that has already been built in shrinking cities, as well as to find a viable solution for operating and maintaining it [Martinez-Fernandez et al., 2012]. This is an issue that both policymakers and academics have not consider with enough attention in the past. Within the next decade, the finding of cost-effective solutions will become a relevant issue. It will not be an easy task, but appropriate solutions must be found [World Economic Forum, 2018].

Economic and demographic trends play a fundamental role in urban shrinkage as they are also part of a larger complex system with interdependencies and feedback loops [Hartt, 2018]. The same complexity can be found in rural areas like those analysed in this paper.

Population loss, ageing, unemployment, lack of economic diversification, social disparities, loss of biodiversity and landscape degradation are common problems in rural areas. Despite public policies have attempted to improve socio-economic and environmental sustainability of these areas, in Europe they still exhibit important imbalances and evolve heterogeneously according to diverse territorial dynamics [SánchezZamora et al., 2014].

The EU 2014-2020 programming cycle is calling for the execution in Italy of 75 Operational Programmes cofinanced using, among others, the European Agricultural Fund for Rural Development (EAFRD), which supports 21 Rural Development Plans (RDP) and 2 National Operational Programmes (NOP).

Sicily benefits from European funds allocated through the European Regional Development Fund, the European Social Fund and the European Agricultural Fund for Rural Development, since it is recognized as a less developed area.

In these terms, the Sicily's Rural Development Program is already putting particular emphasis on the actions for restoring, preserving and enhancing ecosystems as well as on actions addressed to improve the competitiveness of the farm and forestry sectors and to promote social inclusion and economic development in rural areas [EC, 2019].

The Programme is also conceived to support the provision of basic services and village renewal in rural areas, also involving welfare and social care services. Moreover, Local Development Strategies will be implemented through 17 LEADER Local Action Groups and will cover over $83 \%$ of the rural population.

Gibellina, Salaparuta, Poggioreale and Montevago are members of the Partnership of the "Valle del Belice" Local Action Group, together with other eight municipalities, and numerous public research and cultural institutes and private interested stakeholders.

The related community-led local development strategy "Valle del Belice 2020" is aimed at enhancing the 
overall quality of life in the area through the creation of networks among local strategic sectors and the connection with other national and international areas [Lotà, 2016]. This could surely represent an important window of opportunities, but the necessary prerequisite is the effective involvement of local communities.

Successful development dynamics could only rely on an efficient mix of economic growth, social cohesion and environmental sustainability. Nonetheless, the implementation of strong and fruitful policies, capable of reversing the current territorial responses, could not be possible if conditions of economic stagnation, depopulation and environmental degradation will persist.

Innovative development opportunities require actions aimed at introducing wise changes in the socioeconomic structure and the institutional framework, without depleting the environmental capital of rural areas.

For example, the migration fluxes toward rural areas in Europe are a multifaceted phenomenon. They include not only those shaped by economic or political exigencies but also more complex ones that depend on interrelated factors like age, income, labour conditions. Examples refer not only to migrations of unskilled workers toward rural regions, like Alentejo in Portugal [Fonseca, 2008], the attitude of pre-retired British workers [Stockdale, 2004] or the increasing phenomenon of International Retirement Migration (IRM) that is evolving from the initial target of iconic regions to more peripheral ones, like the Marche region in Italy [King et al., 2019].

Understanding these phenomena will give useful hints to define a set of initiatives that can be suitable for facing the depopulation of the Belice Area. Here the key challenge for decision makers will be the definition of an original trajectory that has to be based on a mix of actions. These should include the promotion of integrated agriculture, that will remain the main source of wealth of the Belice, but also measures for attracting new residents, on the basis of the strengths of the area. The Ecosystem Services Approach [De Groot et al., 2010] is vital for evaluating in detail the role of the deeply rooted agricultural tradition of the Valley, also trying to reconsider the role of the Belice river as the structural element for establishing new functional, infrastructural and ecological territorial relations [Pinzello et al., 2012].

The landscape quality and the results of the attempts of the 1980s to introduce contemporary art and high quality architecture, especially but not only in Gibellina [Badami, 2012; Ajroldi, 2012], are the other resources of this area. Even the memory of the disaster can be preserved and valorised, for example transforming the ghost town of Poggireale Vecchia that was abandoned for the reconstructed one (Figure 7) in a minor tourist destination.

Another important example is represented by the Grande Cretto, designed in 1981 by the Italian artist Alberto Burri. It is the transcription of the Gibellina old town's layout, with the aim of encasing and preserving the remnants of the catastrophe, involving the visitor on site dynamically, emotionally, and mnemonically [Folkerts, 2015]. Without the decision of relocating the town far away from its ruins, this great memorial would not exist and so the landscape icon as intrinsic representation of the natural disaster [Folkerts, 2015] and a physical reference of the memory of places and their planning history.

The creation of solid networks at the base of an interconnected system for the fruition of the cultural heritage as well as strategies and interventions for enhancing new forms of sustainable tourism, may become fundamental for the revitalization of the area and for hindering the isolation of centres [Pinzello et al., 2012].

The "cultural economy" [Grodach, 2013], the "ecoturism" [Grenier, 1993], the "energy landscapes" [Blaschke et al., 2013; Wolsink, 2007] intertwined with more traditional planning actions like the revitalization and requalification of historical centres, environmental rehabilitation and restoration, planning and management of the peri-urban interface, sustainable agriculture and planning of rural infrastructures, are all together operations aimed to safeguard, rehabilitate and revitalise inner territorial areas. They are considered necessary to overcome the urban/rural dichotomy and put a new perspective on the concept of service accessibility and on strategies for reversing the depopulation and marginalisation of these areas [Carta, 2015], hinging on two key economic policy assets: improving personal services and triggering local development projects [Barca and Locatelli, 2014].

Town and regional planning can be, once again, the mean for balancing and driving the aforementioned integrated strategies and actions both at the wider and local scale.

However, one important aspect is still often underestimated in the planning and policy practice, that is the evaluation of plans' (or policies') implementation. This holds not only as regard to the assessment of plan or policy alternatives before implementation, but especially it is directed to the research in terms of methodologies to be used for the assessment of those impacts the plans determine on urban development and on the achievement of the main planning goals [Talen, 1996]. Basically, it is quite rare to find evaluations which are 


\section{Viviana Pappalardo et al.}

aimed at returning the picture of actual urban structure in comparison with what was strategically planned. Instead, the practice of evaluating plans, processes and related results should be promoted and could drive future research efforts in studying and designing evaluation methods and their potential regular application to improve planning and policy actions. For example, monitoring urban sprawl or urban abandonment and buildings' underutilization, detecting land-cover changes, checking urban accessibility could strengthen the technical knowledge, yet starting from the collection of existing or new indicators to be used for verifying the outcomes of planning or policy decisions.

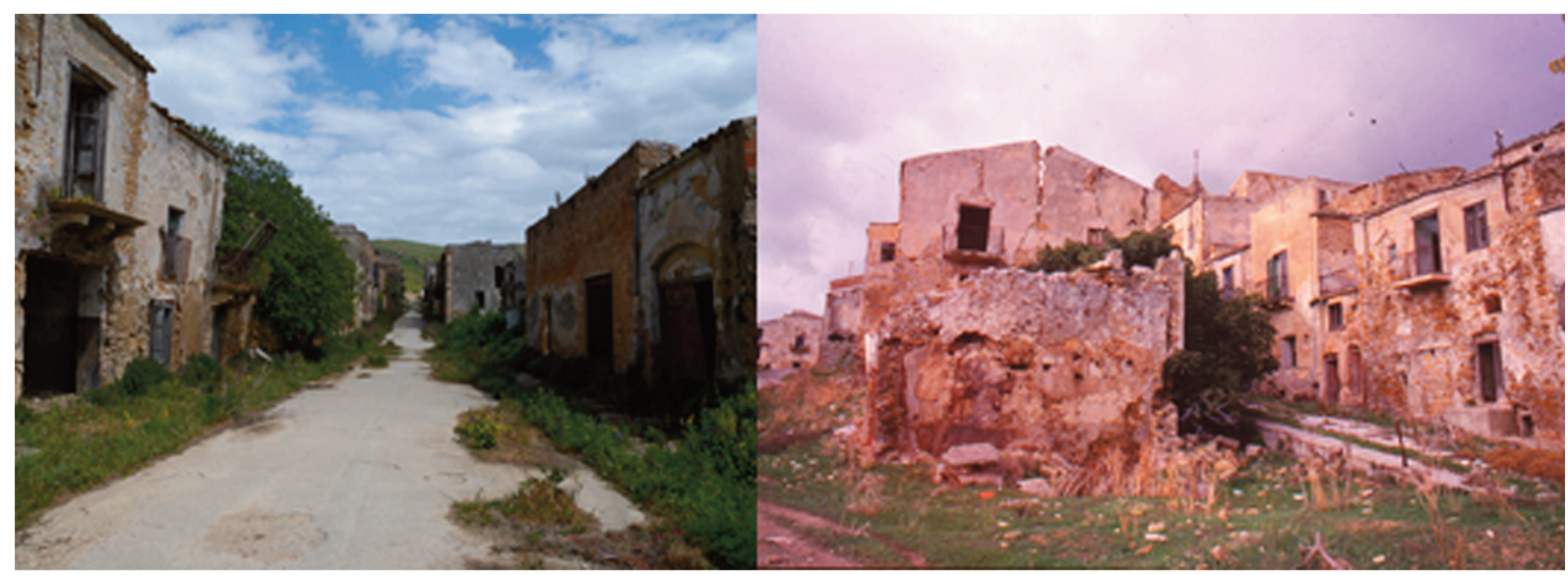

Figure 7. Ruins of Poggioreale (Source: Authors, Francesco Martinico-on the left- Carmelo Monaco-on the right).

\section{Concluding remarks}

Resilience of a place does not only refer to contingencies-such as formulating immediate responses to crises or incidents such as earthquakes, floods or other disasters in vulnerable areas-but also to long-term mitigation and adaptation strategies to face social, economic and environmental challenges [Godschalk, 2003].

After more than 50 years Gibellina, Montevago, Salaparuta, Poggioreale and the rest of the Belice are still struggling to rebound from the destruction caused by the 1968 earthquake. Reinterpreting the reason for the failure of post-disaster reconstruction in the framework of the growing phenomenon of depopulation remains a significant challenge. In the early 1970s, the Belice reconstruction was a test field for applying what were deemed the stateof-art planning approaches of that time. After fifty years, a thorough evaluation of the results of this considerable effort has not been achieved, and the debate is still quite harsh.

Nowadays, the Belice has to contrast reverse dynamics, among which the supply of the housing stock looking for a demand: a difficult process considering that emigration is subtracting young, active and more educated population, the social strata that are more capable of interpreting the complexity of the society, in order to activate new development strategies [Nigrelli, 2019]. In addition, one of the results of the planning approach of the 1970s is the over-dimensioned road infrastructure that nevertheless has increased considerably the accessibility of the area. For instance, Poggioreale is about one hour far from Palermo city centre and other major tourist destinations like the ones in the province of Trapani.

The role of rural landscapes in sustainable development, is increasingly considered as the crucial one [Agnoletti, 2014]. On the contrary, the distance from wealthy metropolitan areas, the poor quality of the reconstructed housing stock and the absence of architectural history, can be considered as the main weaknesses. The major mistakes of the recent past, including the top-down approach that excluded local communities, have to be carefully analysed in order to work out more efficacious solutions.

Successful territorial dynamics of inner (rural) areas are strictly dependent on a wide range of drivers such 
as economic, social and natural assets. Areas able to develop or adapt their capacities and deploy new resources, can also become more resilient in facing the economic crisis [Sanchez-Zamora et al., 2014].

A wise mixture of innovative agriculture, food industry, cultural tourism, and attraction of retirement migration will be the recipe to be tested, in order to redirect the Belice toward a sustainable development perspective.

As a first step, the implementation of new policies and practices capable of generating economic resources and attractiveness have already been placed within the overall framework of European policies and programmes designed for ensuring the sustainable development of rural areas. However, policymakers and planning authorities need continuously to be supported in the design of public policies and related planning actions, starting from the acquisition of basic information on built-up areas and their surrounding landscapes and on the specific features of their natural and anthropic capital.

Further researches and studies on how to apply fruitfully the conceptual framework of resilience to the analysis of territorial dynamics in inner and rural areas are needed, in order to increase the potential impacts on the design of innovative policies. For the same reason, methodologies for the analysis of built-up areas, such as that one applied in this paper, can be useful in contributing to the construction of the learning process, also allowing a deeper insight into existing territories and their current conditions.

\section{Appendix}

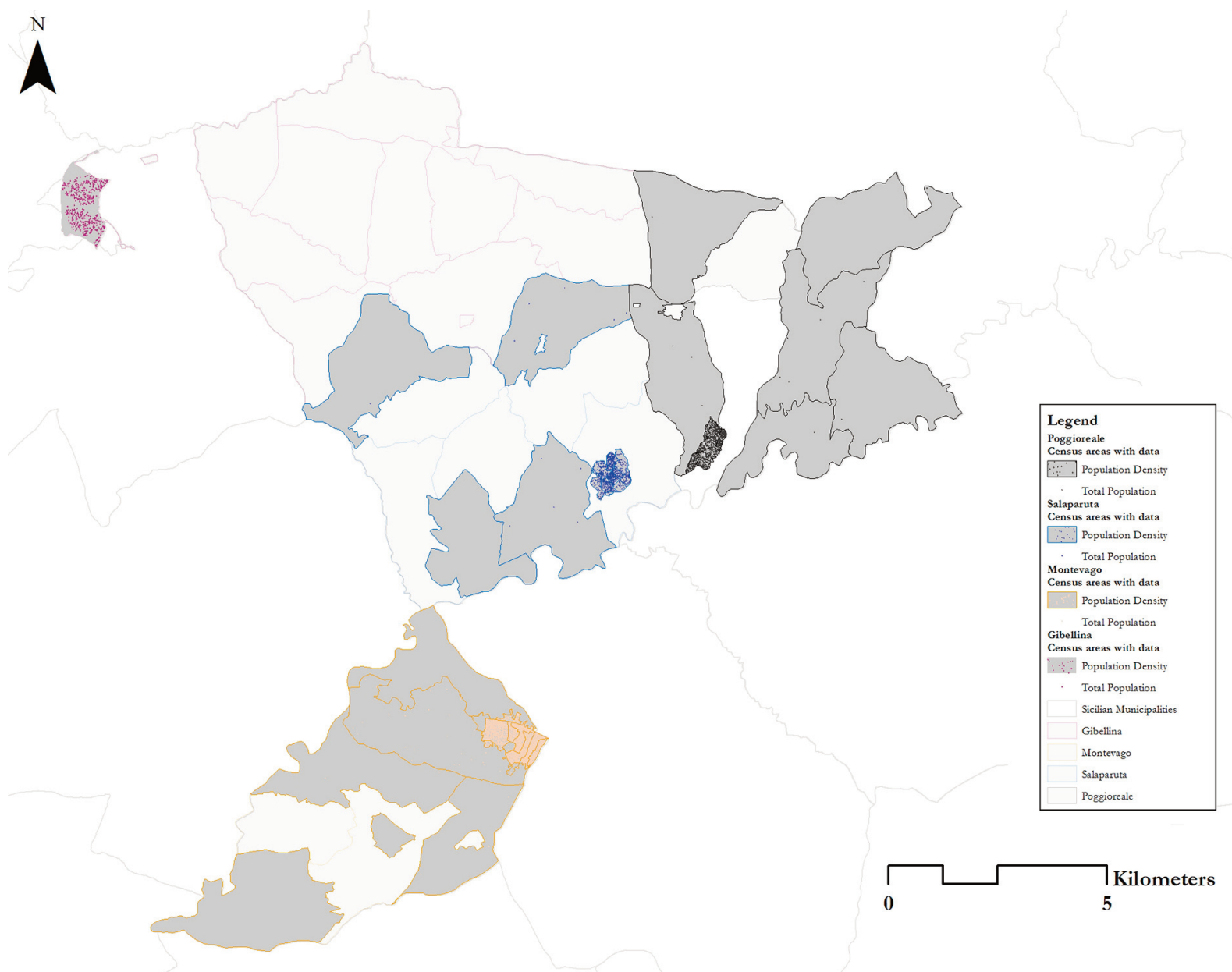

Appendix 1. Population density within the four centres. 


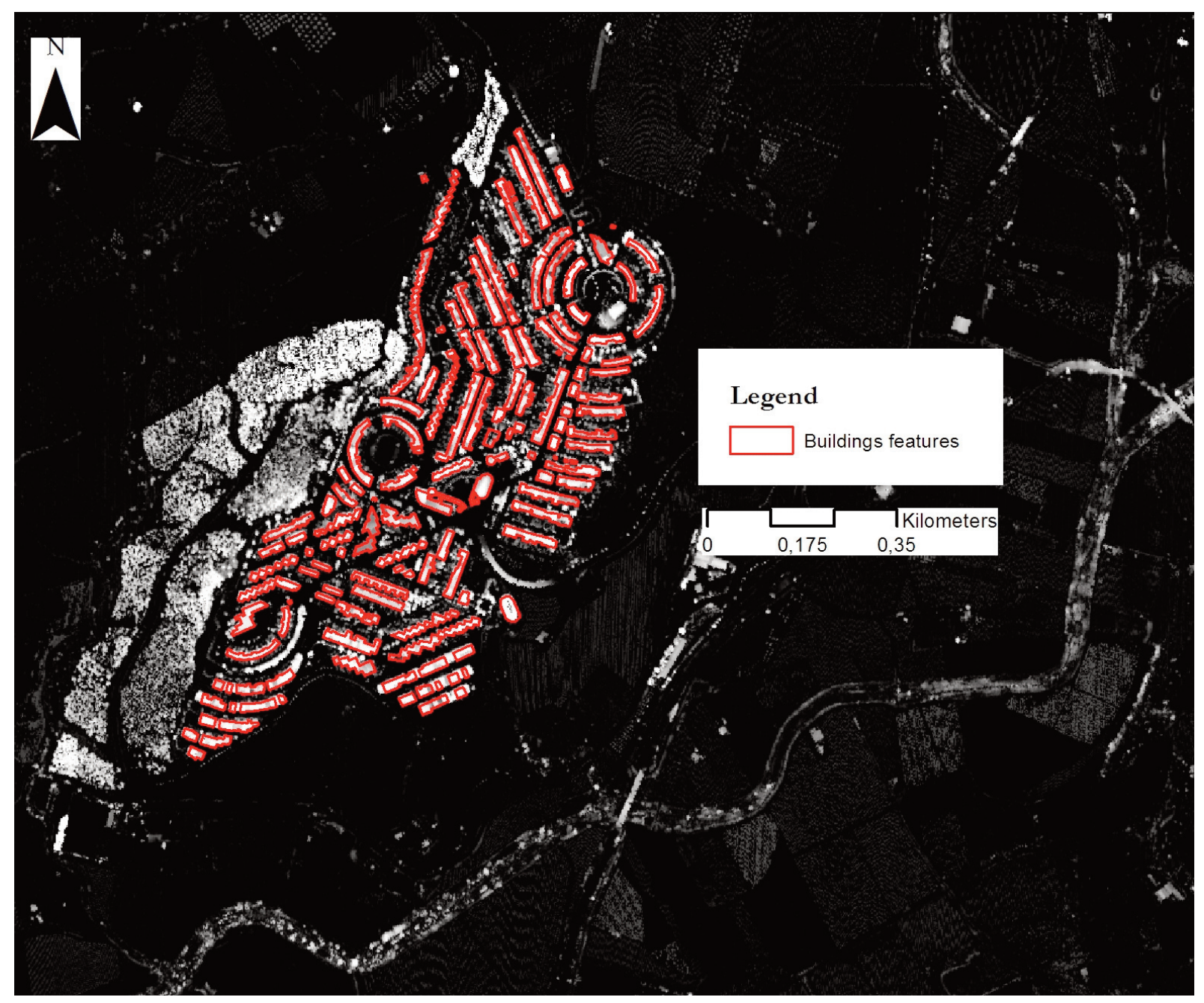

Appendix 2. Minus raster and building layer overlap.

\section{References}

Agnoletti M. (2014). Rural landscape, nature conservation and culture: Some notes on research trends and management approaches from a (southern) European perspective, Landscape Urban Plann., 126, 66-73.

Ajroldi, C. (2012). Restoration of the modern: Designs at Gibellina | [Restauro del moderno: progetti a Gibellina], Territorio, 62, pp. 95-101

Allan, P., M. Bryant, C. Wirsching, D. Garcia, M.T. Rodriguez (2013). The Influence of Urban Morphology on the Resilience of Cities Following an Earthquake, J. Urban Des., 18(2), 242-262.

Arup (2014). City resilience index, Report available at:

https://www.arup.com/perspectives/publications/research/section/city-resilience-index

Badami A. (2012). L'investimento in arte e cultura per fondare una città e generare una comunità a Gibellina. Intervista a Ludovico Corrao, Archivio Di Studi Urbani E Regionali, 105, 66-86

Barca, F., Lucatelli, S. (2014) edited by, A strategy for inner areas in Italy: definition, objectives, tools and governance, Materiali Uval Series, 31.

Blaschke T., M. Biberacher, S. Gadocha, I. Schardinger (2013). “Energy landscapes”: Meeting energy demands and human aspirations, Biom. Bioen., 55, 3-16.

Cagnardi, A. (1981). BELICE 1980. Luoghi problemi progetti dodici anni dopo il terremoto, Venezia: Marsilio, 166. Campanella, T.J. (2008). Urban Resilience and the Recovery of New Orleans, J. Am. Plann. Assoc., 72( 2), 141-146. 
Campo, G. (2005). Anabasi di Sicilia. Dalla foce alle sorgenti di fiumi ormai senz'acqua, Catania: Prova d'Autore, 170. Carta, M. (2015). Innovazione, Circolarità e Sviluppo Locale. La sfida dei territori interni, in M. Carta, D. Ronsivalle, Territori Interni. La pianificazione integrata per lo sviluppo circolare: metodologie, approcci, applicazioni per nuovi cicli di vita, Roma: Aracne, 244.

Clemente, M., L. Salvati (2017). “Interrupted” Landscapes: Post-Earthquake Reconstruction in between Urban Renewal and Social Identity of Local Communities, Sustainability, 9(11), https://doi.org/10.3390/su9112015

De Groot, R. Alkemade, L. Braat, L. Hein, L. Willemen (2010). Challenges in integrating the concept of ecosystem services and values in landscape planning, management and decision making, Ecol. Compl., 7(3), 260-272.

EC-European Commission (2019). Factsheet on 2014-2020 Rural Development Programme for Sicily, factsheet, available at: https://ec.europa.eu/info/sites/info/files/food-farming

fisheries/key_policies/documents/rdp-factsheet-italy-sicily_en.pdf

ENRD-European Network for Urban Development (2018). Strategy for inner areas Italy, working paper, available at: https://enrd.ec.europa.eu/sites/enrd/files/tg_smart-villages_case-study_it_0.pdf

Folkerts, T. (2015). Landscape as memory, J. Landsc. Archi., 10, 1, 68-77.

Fonseca M. L. (2008). New Waves of Immigration to Small Towns and Rural Areas in Portugal, Popul. Space Pl., 14, 6, 525-535.

Godschalk D.R. (2003). Urban Hazard Mitigation: Creating Resilient Cities, Nat. Haz. Rev., 4, 3, 136-143.

Grenier, D., Kaae, B.C., Miller, M.I., Mobley, R.W. (1993). Ecoturism, landscape architecture and urban planning, Landscpe and Urban Planning, 25(1-2), 1-16.

Grodach C. (2013). Cultural Economy Planning in Creative Cities: Discourse and Practice, International Journal of urban and regional research, 37, 5, 1747-1765.

Hartt, M.D. (2018). How cities shrink: Complex pathways to population decline, Cities, 75, 38-49.

Hassler U. and N. Kohler (2014). Resilience in the built environment, Build. Res. Info., 42, 2, 119-129.

INGV (2019), I terremoti del '900: Il terremoto del 15 gennaio 1968 nella Valle del Belice (Parte 1), https://ingvterremoti.wordpress.com/2018/03/29/i-terremoti-del-900-il-terremoto-del-15-gennaio-1968nella-valle-del-belice-parte-1/

Xu J., Lu Y. (2018). Towards an earthquake-resilient world: from post-disaster reconstruction to pre-disaster prevention, Environ. Haz., 17, 4, 269-275.

King R., E. Cela, G. Morettini, T. Fokkema (2019). The Marche: Italy's new frontier for international retirement migration, Popul. Space Pl., 25, 4, doi:10.1002/psp.2241.

La Rosa D., M. Spyra, L. Inostroza (2016). Indicators of Cultural Ecosystem Services for urban planning: A review, Ecology Indicators, 61, Part 1, 74-89.

Lòpez Moreno E., Z Gonzàles Blanco Z., (2014.) Ghost Cities and Empty Houses: Wasted Prosperity, Am. Intl. J. Soc. Sci., 3, 2 .

Lotà, V. (2016). Strategia di sviluppo locale di tipo partecipativo “Valle del Belice 2020" del gruppo di Azione Locale "Valle del Belice”, galvalledelbelice.it, url: https://galvalledelbelice.it/il-gal/il-piano-di-azione-locale-pal/

Martinez-Fernandez, C., I. Audirac, S. Fol, E. Cunningham-Sabot (2012). Shrinking Cities: Urban Challenges of Globalization, Intl. J. Urban Region. Res., 36, 2, 213-225.

Martinico F. (2017). I paesaggi della riforma agraria nei piani di area vasta in Sicilia, in G. Bonini G. and F. C. Nigrelli (eds), I Paesaggi della Riforma Agraria. Storia Pianificazione e Gestione, Gattico: Edizioni Istituto Alcide Cervi, 389.

Martinico, F. (2001). Il territorio dell'industria. Nuove strategie di pianificazione delle aree industriali in Europa, Roma: Gangemi, 286.

Maattanen N., (2019). Unlocking housing wealth to foster the silver economy https://silvereconomyforum.eu/wpcontent/uploads/2019/07/Silvereconomypaperi_etlapohjalla.pdf

Meerow, S., J. P. Newell and M. Stults, M. (2016). Defining urban resilience: A review. Landscape and Urban Planning, 147, 38-49.

Murgante, B., F. Rotondo (2012). A Geostatistical Approach to Measure Shrinking Cities: The Case of Taranto, Stat. Meth. Spat. Plann. Monit., 119-142.

Nigrelli F.C. (2019). Paesaggio e democrazia nelle aree interne, in Bonini G. and Pazzagli R. (eds), Paesaggio e Democrazia. Partecipazione e governo del territorio nell'età della Rete, Gattico: Edizioni Istituto Alcide Cervi.

Pacelli, M, E. S. De Felice (1977). Belice: un esempio, Napoli: Editoriale Scientifica s.r.l., 81. 


\section{Viviana Pappalardo et al.}

Piazza, P.A. (1995). Problemi di identità strutturale nella città antisismica. In, Sanfilippo, E.D., P. La Greca (1995). Piano e progetto nelle aree a rischio sismico- Planning and design in seismic risk areas, Roma. Gangemi Editore, 384.

Pinzello, I., Canale, L., Giampino, A., Scaduto, M.L., Todaro, V. (2012). Pianificazione ricostruzione. Opportunità e strategie per il rilancio della valle del Belice, Planum the Journal of Urbanism, 25(2).

Renna, A., A. De Bonis, G. Gangemi (1979). Costruzione e progetto. La valle del Belice, Clup, Milano.

Sánchez-Zamora, P., R. Gallardo-Cobos, F. Ceña-Delgado (2014). Rural areas face the economic crisis: Analyzing the determinants of successful territorial dynamics, J. Rur. Stu., 35, 11-25.

Scibilia, F. (2016). The reconstruction of Gibellina after the Belice earthquake of 1968, International Planning History Society proceedings, https://doi.org/10.7480/iphs.2016.2.1245

Sessa, E. (2012). Architettura e forma urbana nella ricostruzione del Belice. In: Nobile, M.R., D. Sutera (2012) Catastrofi e dinamiche di inurbamento contemporaneo. Città nuove e contesto, Palermo: Edizioni Caracol.

Stockdale A. (2006). The Role of a “Retirement Transition” in the Repopulation of Rural Areas, Popul. Spa. Pla., 12, 1-13.

Talen, E. (1996). After the Plans: Methods to Evaluate the Implementation Success of Plans, J. Plann. Edu. Res., 16, 2, 79-91.

World Economic Forum (2018). In an urbanizing world, shrinking cities are a forgotten problem, www.weforum.org.

Wolsink M. (2007). Planning of renewables schemes: Deliberative and fair decision-making on landscape issues instead of reproachful accusations of non-cooperation, Ener. Policy, 35(5) 